Article

\title{
Effect and Interaction of $\beta$-Lactoglobulin, Kappa Casein, and Prolactin Genes on Milk Production and Composition of Awassi Sheep
}

\author{
Khaleel Jawasreh ${ }^{1, *}$, Ahmad Al Amareen ${ }^{2}$ and Pauline Aad ${ }^{3}$ \\ 1 Department of Animal Production, Jordan University of Science and Technology (JUST), Irbid 22110, Jordan \\ 2 Livestock Directorate, National Agriculture Research center (NARC), Albaqa'a 19381, Jordan; \\ ahmad_alathamna@yahoo.com \\ 3 Department of Sciences, Notre Dame University Louaize, Zouk Mosbeh 1211, Lebanon; paad@ndu.edu.lb \\ * Correspondence: kijawasreh@just.edu.jo; Tel.: +962-777420884
}

Received: 31 May 2019; Accepted: 18 June 2019; Published: 21 June 2019

check for updates

Simple Summary: Beta-lactoglobulin $(\beta-L G)$, prolactin (PRL), and Kappa casein (CSN3) all contribute to the determination of milk production and composition, but have not been assessed in local Awassi sheep. Therefore, our aim was to analyze the contribution of these genes in milk production and composition traits in commercial Awassi ewe population by genotyping and sequencing these genes. Our results showed the prevalence of the different variations (alleles) of the tested genes in the Awassi population, and no association among $\beta-L G$ and CSN3 polymorphic genotypes and milk production, or PRL and fat \%. Also, all 3 genes help determine the milk production potential of Awassi ewes and help assess milk components, and thus can be used in breeding programs to select for milk potential.

\begin{abstract}
A participatory animal-breeding program was applied to 9 commercial Awassi sheep flocks in Jordan. This study aimed to assess the influence of Beta-lactoglobulin $(\beta-L G)$, Prolactin $(P R L)$, and Kappa casein (CSN3) genes, genotypes and their interaction on milk production and composition traits of 167 genotyped Awassi ewes via Polymerase Chain Reaction (PCR) followed by sequencing. Allele frequencies for the two variants were 0.42 and 0.58 for $\beta-L G, 0.82$ and 0.18 for $P R L$, and 0.92 and 0.08 for CSN3. No association was found among $\beta-L G$ and CSN3 polymorphic genotypes with milk production traits. However, ewes with $P R L$ AA genotype showed higher milk production, $\beta$ - $L G$ $\mathrm{AB}$ was associated with lowest fat $\%$, high solid not fat (SNF) $\%$, protein $\%$, and lactose $\%$. $\beta-L G$ BB was associated with highest milk density. $P R L, \beta-L G$, and CSN3 polymorphic genotypes were differentially associated with milk production and component traits. Furthermore, $\beta-L G \times P R L$ interaction showed the highest milk production and fat $\%$; $\beta$ - LG $\times P R L$ recorded the highest $\mathrm{SNF} \%$, protein $\%$, lactose $\%$, and milk density, while the PRL $\times$ CSN3 had the highest fat $\%$ and SNF\%. The enhancing effects of these gene interactions can be incorporated in Awassi breeding programs to improve milk production and composition.
\end{abstract}

Keywords: Awassi sheep; gene interaction; milk components

\section{Introduction}

The dairy industry is a crucial cog in the agricultural economy of many countries. Therefore, milk yield and its components are among the major goals targeted by animal geneticists [1]. Recently, increasing interest in sheep milk has led to extensive studies aiming to explore the local sheep breed's genetic potential in milk production [2]. Awassi is the most common breed of sheep in Middle East countries where its products, including meat, milk, and wool, play an important socioeconomic role in Jordan. Awassi lambs are profitable and the milk of Awassi ewes is a commodity valued by farmers for 
its ability to cover annual production costs. For this reason, Awassi daily milk production has been enhanced via genetic selection from $0.5 \mathrm{~kg}$ to $1.2 \mathrm{~kg}$ [3]. Meanwhile, milk production and composition in Mediterranean countries was observed to fluctuate within and between flocks and countries as a result of different environmental factors and variations within and between Awassi genotypes [4-9]. In the past, animal breeders have made effective efforts to improve the performance of livestock by artificial selection and breeding to increase the frequency of certain desirable traits. This only involved the direct use of phenotypic observations without any knowledge of the underlying molecular information. Therefore, there is a need to adopt methods of selection based on genomic queues [10].

Milk protein polymorphisms are of great importance in the dairy industry and animal-breeding programs due to its association with quantitative and qualitative milk traits and its potential use in genetic selection programs of dairy sheep breeds [11]. Many studies with diverse breeds of dairy sheep have indicated Beta-lactoglobulin $(\beta-L G)$, Prolactin $(P R L)$ and Kappa casein (CSN3) as promising candidate genes for milk production and composition [2,12-16].

Beta-lactoglobulin, coded by the $\beta-L G$ gene, is synthesized by the secreting cells of the mammary gland. $\beta-L G$ is the primary whey protein in ruminant's milk and accounts for approximately 17 to $22 \%$ of total milk proteins [15]. The $\beta$-LG gene is located on ovine chromosome 3 [17], and exon number 2 of $\beta-L G$ revealed three allelic polymorphisms (A, B and $C$ ) based on different amino acid changes. The alleles $\mathrm{A}$ and $\mathrm{B}$ (Tyr/His) differ at the amino acid position 20 [18] and the genetic variant $\mathrm{C}$ differs from variant $A$ by an amino acid exchange at position 148 (Arg/Gln) (GenBank accession No. X12817). The most common genetic variants detected in all studied sheep breeds are A and B, while the variant $C$ is regarded as rare, and only found with low frequencies in Carranzana, Black Merino and White Merino breeds [15]. Subsequent studies have demonstrated the $\beta$ - $L G$ gene's polymorphic effect on milk components including yield, protein, fat, and lactose content $[14,19,20]$ as well as the impact of protein genetic variants on the properties of milk [2].

Prolactin, coded by the PRL gene, is a lactogenic hormone found in many species. The PRL gene plays a key role in the development of the mammary gland and milk secretion; its depletion in sheep provokes a severe reduction in milk production [21], suggesting that $P R L$ is a functional candidate gene contributing to variations in milk production. Many researchers suggested the association of $P R L$ gene polymorphisms with milk yield and composition traits in different dairy sheep breeds [13,14,16,22]. The PRL gene is in a region of the ovine chromosome 20 with putative quantitative trait locus (QTL) for milk yield and composition [23]. Thus, PRL is primarily responsible for the synthesis of fat, proteins, and all other major components of milk [24]. These characteristics make PRL a strong candidate gene for milk traits, and potentially be used as a positional marker gene associated with milk yield and composition.

The four caseins ( $\alpha S 1_{-}, \alpha S 2-, \beta$ - and $\kappa$-casein) are the major proteins in sheep milk, accounting for about $80 \%$ of total protein in milk [24]. Among the 4 caseins, $\mathcal{\kappa}$-casein (CSN3) accounts for approximately $15 \%$ of total casein, and thus represents one of the most important proteins due to its essential role in micelle formation and stabilization [2], and thus determines the manufacturing properties of milk. Therefore, CSN3 could be used as a positional marker gene associated with high milk production and milk composition improvement. Molecular analyses of ovine CSN3, mainly of exon 4, revealed synonymous and non-synonymous sequence differences [12,25,26]. However, limited information about the association of this marker with milk yield and composition in dairy sheep could be found in the literature. One positive association between CSN3 gene polymorphism and lactose percentage has been reported in Zel sheep [20]. Staiger et al. [16] and Gras et al. [12] reported that the polymorphisms found in the CSN3 gene did not have any significant effect on milk yield and composition traits. Hence, substantiating phenotypic data with molecular information to improve milk and its composition is critical for the future of dairy sheep industry [16].

The present study screens some Awassi genetic loci for possible variants in the $\beta$ - $L G, P R L$, and CSN3 genes and establishes their frequency in commercial Awassi sheep flocks in the ultimate objective of investigating the effect of these genotypes and their interaction on milk production and composition 
traits. To our great knowledge, this is the first study that investigates the association of some molecular information and milk traits in the commercial Awassi flocks in Jordan.

\section{Materials and Methods}

\subsection{Animal and Sample Collection}

All experimental protocols involving animals were approved by the Animal Care and Use committee (ACUC), Jordan University and Science Technology (JUST), approval Number 16/3/3/578.

A participatory animal-breeding program was performed in the South, North, and middle of Jordan; this program was supported by Livestock and Range land research directorate of the National center for agricultural research and Extension (NCARE) (recently renamed to National Agricultural Research Center (NARC)) staff. Specific farmers were appointed before starting the program and several meetings were performed with the livestock owners. A total number of 928 ewes that belong to 9 flocks (three in each region) were targeted through the participatory animal-breeding program.

After specifying the collaborating farms, semi-structural questionnaires were completed for each animal in the flock covering parity and age of dam, sex and type of birth of the newborns and available sires and dams in addition to all related environmental factors. All animals $(\mathrm{n}=928)$ were monitored and milk data were recorded directly by three specialized teams in each region (North, middle, and South). The exhaustive milk and pedigree data however was collected from two commercial Awassi flocks, selected based on the availability and ability for collecting performance data, and located in the northern part of Jordan. Data were collected from the two farms during 5 lambing and milking seasons. The team of NARC collected the data by identifying the sires in the breeding seasons, recording lamb information (birth and weaning weights, date of birth and weaning, dam weight at lambing, milk tests as described below), after which the trained farmers continued data collection under the supervision of the livestock research director. The farmers were supplied by special separation cages. They measured milk yield with graded milk cylinders and recorded its weight with small portable digital weighing scales (up to $30 \mathrm{~kg}$ ) or portable digital mobile weighing scales (up to $200 \mathrm{~kg}$ ).

Blood samples for DNA harvesting were carefully collected from the jugular vein of the 167 Awassi ewes ( 2 to 6 years old) that were born to 31 sires using vacuum tubes treated with $0.25 \%$ Ethylene Diamine Tetraacetic Acid (EDTA) (BD Vacutainer Systems, Plymouth, UK) and stored at $-20{ }^{\circ} \mathrm{C}$ until DNA isolation.

\subsection{Milk Samples and Analysis}

A total of 391 full lactation records on 167 ewes were collected from 2007 and 2011 from the two commercial farms identified. Milk was collected manually via hand milking by skilled workers. Through the pre-weaning period, ewes were milked once a day followed by analyzing milk amount of each ewe twice a day (morning and evening), at biweekly intervals. To measure the amount of milk produced during the suckling period (60 days), lambs were isolated from their dams $12 \mathrm{~h}$ before morning milking. Ewes were dried off when their milk production was reduced to less than $100 \mathrm{~mL}$. The average lactation length, including suckling and milking periods was 115 days. Through the suckling period, ewes were milked once, keeping half of the milk for the lamb's consumption, so the milk amount was multiplied by 2 . While in the post-weaning period ewes were milked twice a day (morning and evening), milk amounts were averaged and multiplied by the interval between the two successive tests period then summed to obtain the total milk yield (TMY). Test-Day Milk yield (TDM) was calculated by dividing TMY by Lactation Period of each ewe. Approximately $50 \mathrm{~mL}$ of milk sample was collected from the morning milk of each ewe to determine basic composition of fat $\%$, protein $\%$, lactose $\%$, solids-not-fat $\%$ (SNF\%) and milk density g/ $\mathrm{cm}^{2}$. Milk composition ( $\mathrm{n}=986$ milk samples) was analyzed using a Milko Scan (Minor Type 78100, FOSS Electric, Hillerød, Denmark) available at JUST university. 


\subsection{Genomic DNA Extraction and Polymerase Chain Reaction (PCR)}

Genomic DNA was extracted using Wizard Genomic DNA Extraction Kit (OMGA-Bio-Tek, Inc., Madison., WI, USA). DNA quality was tested using 1.5\% agarose gel electrophoresis. Polymerase chain reaction (PCR) was used for amplifying the studied genes; using primers targeting exon II of the $\beta-L G$, intron 2 of PRL as shown in Table 1 . Primers for CSN3 were designed, using primer 3 (http://frodo.wi.mit.edu/primer3/), to target part of the intron 3 and the totality of exon 4 and part of intron 4, using the available nucleotide sequence (Accession No.: 443394) on the NCBI GenBank database. PCR mix (HOT FIREPol DNA Polymerase; Solis BioDyne, Estonia) was carried out in a total volume of $20 \mu \mathrm{Lcontaining} 10 \mu \mathrm{L}$ of nuclease-free water, $2 \mu \mathrm{L}$ of genomic DNA (100 ng/ $\mu \mathrm{L})$ as a template, $2 \mu \mathrm{L}$ of each primer, and $4 \mu \mathrm{L}(5 \mathrm{U} / \mu \mathrm{L})$ of Taq DNA polymerase (Eppendorf AG, Hamburg, Germany). Primer sequences, annealing temperature, and restriction enzymes used for genotyping are shown in Table 1. The PCR reaction was carried out in the following conditions of $95^{\circ} \mathrm{C}$ for $5 \mathrm{~min}$ for initial denaturation followed by 33 cycles at $95^{\circ} \mathrm{C}$ for $30 \mathrm{~s}$ of denaturation, $40 \mathrm{~s}$ annealing (Table 1 ) and extension each at $72{ }^{\circ} \mathrm{C}$, and a final extension step at $72{ }^{\circ} \mathrm{C}$ for $7 \mathrm{~min}$.

Table 1. Primer information and restriction information for genes of interest.

\begin{tabular}{|c|c|c|c|c|c|c|}
\hline Gene & & Primers $\left(5^{\prime} \rightarrow 3^{\prime}\right)$ & $\mathrm{TM}\left({ }^{\circ} \mathrm{C}\right)$ & $\begin{array}{c}\text { PCR } \\
\text { Product (bp) }\end{array}$ & RE & Reference \\
\hline $\begin{array}{l}\text { Beta-lactoglobulin } \\
\qquad(\beta-L G)\end{array}$ & $\begin{array}{l}\mathrm{F} \\
\mathrm{R}\end{array}$ & $\begin{array}{l}\text { CTCTTTGGGTTCAGTGTGAGTCTTG } \\
\text { CACCATTTCTGCAGCAGGATCTC }\end{array}$ & 58 & 301 & RsaI & [27] \\
\hline Prolactin $(P R L)$ & $\begin{array}{l}\mathrm{F} \\
\mathrm{R}\end{array}$ & $\begin{array}{l}\text { ACCTCTCCTCGGAAATGTTCA } \\
\text { GGGACACTGAAGGACCAGAA }\end{array}$ & 56 & 1209 & HaeIII & {$[28]$} \\
\hline $\begin{array}{l}\text { Kappa Casein } \\
\quad(C S N 3)\end{array}$ & $\begin{array}{l}\mathrm{F} \\
\mathrm{R}\end{array}$ & $\begin{array}{c}\text { CTGGGTTCACTATTCCCAATG } \\
\text { TTGCTCATTTACCTGCGTTG }\end{array}$ & 57 & 680 & * & $\begin{array}{l}\text { Accession \# } \\
443394\end{array}$ \\
\hline
\end{tabular}

\subsection{Restriction Fragment Length Polymorphism (RFLP) Analysis}

$\beta-L G$ and $P R L$ genes variants were identified by the PCR-RFLP method. The amplified $\beta-L G$ gene fragment (301 bp) was digested by RasI restriction enzyme for $2 \mathrm{~h}$ at $37^{\circ} \mathrm{C}$. Restriction products were separated in a $2 \%$ agarose gel with ethidium bromide and visualized under ultraviolet (UV) light. The amplified $P R L$ gene fragment (1209 bp) was restricted with HaeIII endonuclease at $37^{\circ} \mathrm{C}$ for $3 \mathrm{~h}$. The RFLP profile was visualized by the same way as for $\beta-L G$.

\subsection{Sequencing Analysis}

Sequences were obtained using the same primers used for PCR amplification as shown in Table 1. The PCR products of the different genotype patterns of the CSN3 gene were purified and sequenced by Macrogen Incorporation (Seoul, South Korea) to identify the single nucleotide polymorphisms (SNPs) found in these different genotype patterns. Ten randomly chosen PCR samples for each genotype of $\beta-L G$ were sequenced from both directions to confirm the results obtained by PCR-RFLP technique. Sequence analysis and alignments were carried out using BioEdit program version 5.0.6. [29].

\subsection{Statistical Analysis}

The genotype and allelic frequencies of the $\beta-L G, P R L$, and CSN3 loci were calculated using Pop-Gene 32 package version 1.31 program [30]. A chi-square $(\chi 2)$ test was performed to test the goodness of fit to Hardy-Weinberg equilibrium expectations for the distribution of genotypes. The effects of genotypes of $\beta-L G, P R L$, and CSN3, and their interactions on the traits studied were analyzed using the least-squares method as applied in a mixed-model procedure of SAS/ STAT ${ }^{\circledR}$ software (SAS Institute Inc., Cary, NC, USA, v9.1). Two statistical models were used as described below. 
The first model used for the milk production traits analysis was:

$$
\begin{gathered}
\text { Yijklnmop }=\mu+\text { BLGi }+ \text { PRLj }+ \text { CSNk }+ \text { Pl }+ \text { Sm }+ \text { SYn }+ \text { BoDWo }+(B L G \times P R L) i j+ \\
(\text { BLG } \times \text { CSN }) i k+(P R L \times C S N) j k+\text { eijklmnop }
\end{gathered}
$$

where:

- $\quad$ Yijklnmop = the studied traits;

- $\quad M=$ overall mean of the total milk yield or test-day milk yield;

- $\quad$ BLGi $=$ fixed effect of the ith genotype at $\beta-L G$ locus $(I=A A, A B$ and $B B)$;

- $\quad P R L j=$ fixed effect of the $j$ th genotype at $P R L$ locus $(j=\mathrm{AA}, \mathrm{AB}$ and $\mathrm{BB}) ;$

- $\quad C S N k=$ fixed effect of the $k$ th genotype at CSN3 locus $(k=T T$ and TC);

- $\quad \mathrm{Pl}=$ fixed effect of the lth parity or number of lambing $(1=1,2,3,4,5$ and 6);

- $\quad S m=$ random effect of $m$ th sires $(m=1,2$ to 31$)$;

- $\quad$ SYn = fixed effect of the $n$th year-season of lambing ( $n=2007$ to 2011);

- $\quad$ Bo = linear regression coefficient dam weight at lambing;

- $\quad$ DWo = dam weight at lambing as covariate;

- $\quad(B L G \times P R L) \mathrm{ij}=$ interaction between $\beta$ - $L G$ genotypes and PRL genotypes $(\mathrm{ij}=\mathrm{AAAA}, \mathrm{AAAB}$, $\mathrm{AABB}, \mathrm{ABAA}, \mathrm{ABAB}, \mathrm{ABBB}, \mathrm{BBAA}, \mathrm{BBAB}$, and $\mathrm{BBBB})$;

- $\quad(B L G \times C S N)$ ik = interaction between $\beta-L G$ genotypes and CSN3 genotypes (ik = AATT, AATC, ABTT, ABTC, BBTT, and BBTC);

- $\quad(P R L \times C S N) \mathrm{j} \mathrm{k}=$ interaction between $P R L$ genotypes and CSN3 genotypes $(\mathrm{jk}=\mathrm{AATT}, \mathrm{AATC}$, ABTT, ABTC, BBTT, BBTC);

- $\quad$ Eijklmnop $=$ random errors with the assumption of $\mathrm{N}(0, \sigma 2)$.

The second model used for the milk composition traits analysis:

$$
\begin{gathered}
\text { Yijklmno }=\mu+\text { BLGi }+ \text { PRLj }+ \text { CSNk }+P l+S m+\beta n T D M n+(B L G \times P R L) i j+ \\
(\text { BLG } \times \text { CSN }) i k+(P R L \times C S N) j k+e i j k l m n o
\end{gathered}
$$

where:

- $\quad$ Yijklnmo = the studied traits;

- $\quad \mathrm{M}=$ overall mean of Fat $\%$; protein $\%, \mathrm{SNF} \%$, Total solids, lactose $\%$, and density $\left(\mathrm{g} / \mathrm{cm}^{2}\right)$

- $\quad \quad B L G i=$ fixed effect of the ith genotype at $\beta-L G$ locus (I = AA, AB and BB);

- $\quad \quad \quad P R L j=$ fixed effect of the $j$ th genotype at $P R L$ locus ( $\mathrm{j}=\mathrm{AA}, \mathrm{AB}$ and $\mathrm{BB}) ;$

- $\quad \mathrm{CSNk}=$ fixed effect of the kth genotype at CSN3 locus ( $\mathrm{k}=\mathrm{TT}$ and TC);

- $\quad \mathrm{Pl}=$ fixed effect of the lth parity or number of lambing $(1=1,2,3,4,5$ and 6$)$;

- $\quad S m=$ random effect of $m$ th sires $(m=1,2, \ldots, 31)$;

- $\quad B n=$ linear regression coefficient TDM.

- $\quad$ TDMn = TDM covariant.

- $\quad(B L G \times$ PRL $) i j=$ interaction between $\beta$ - $L G$ genotypes and PRL genotypes $(\mathrm{ij}=$ AAAA, AAAB, $\mathrm{AABB}, \mathrm{ABAA}, \mathrm{ABAB}, \mathrm{ABBB}, \mathrm{BBAA}, \mathrm{BBAB}$, and $\mathrm{BBBB})$;

- $\quad(B L G \times C S N)$ ik = interaction between $\beta-L G$ genotypes and CSN3 genotypes (ik = AATT, AATC, ABTT, ABTC, BBTT, and BBTC);

- $\quad($ PRL $\times$ CSN)jk = interaction between PRL genotypes and CSN3 genotypes $(\mathrm{jk}=$ AATT, AATC, ABTT, ABTC, BBTT, and BBTC);

- $\quad$ Eijklmno $=$ random errors with the assumption of $\mathrm{N}(0, \sigma 2)$.

The three-ways interaction effects among the three genes and the flock effect were removed from the model as it was not significant. For all statistical comparisons, a probability level of $p<0.05$ was considered to be statistically significant. 


\section{Results}

\subsection{Descriptive Statistics}

The means, standard error, and coefficients of variation for milk production and composition traits are presented in Table 2. The mean milk production and composition traits showed very small standard errors but high coefficient of variations for milk production traits and fat $\%$ but relatively average $\mathrm{CV}$ for protein and lactose $\%$, indicating a very diverse flock of Awassi, and further strengthening the potential for selection for both traits in these commercial flocks.

Table 2. Descriptive statistics of milk production and milk composition traits.

\begin{tabular}{ccccc}
\hline Milk Trait & No. Records & Mean & SE & CV (\%) \\
\hline Milk production (Kg) & & & & \\
TMY & 391 & 96.8 & 2.60 & 53.0 \\
TDM & 391 & 0.882 & 0.02 & 45.0 \\
\hline Milk composition & & & & \\
Fat\% & 917 & 5.80 & 0.05 & 25.7 \\
SNF\% & 986 & 9.74 & 0.03 & 8.30 \\
Protein\% & 986 & 3.90 & 0.02 & 13.0 \\
Lactose\% & 986 & 5.10 & 0.02 & 13.9 \\
Density g/cm ${ }^{2}$ & 986 & 34.3 & 0.10 & 9.4 \\
\hline
\end{tabular}

TMY: Total Milk Yield; TDM: Test-Day Milk; SNF: Soluble-Not-Fat; SE: Standard Error; CV: Coefficient of Variation (\%).

\subsection{PCR-RLFP Assay of $\beta$-LG and PRL Genes}

$\beta-L G$ gene fragment was successfully amplified using PCR and resulted in a single product of $301 \mathrm{bp}$. Digestion by RsaI restriction enzyme revealed three genotypes designated as AA (241 and $60 \mathrm{bp}), \mathrm{AB}(241,175,66$ and $60 \mathrm{bp})$ and $\mathrm{BB}(175,66$ and $60 \mathrm{bp})$ (Figure 1A) or by sequence designated as TT, TC and CC (Supplementary, Figure S2 and Table 3). For the PRL gene, a 1.209 bp fragment was amplified successfully. Digestion of the PCR amplified PRL gene by HaeIII restriction endonuclease is shown in Figure $1 \mathrm{~B}$ and revealed two alleles $(\mathrm{A}$ and $\mathrm{B})$ of three genotypes with different sizes consisting of $\mathrm{AA}(540,370,147$, and $152 \mathrm{bp}), \mathrm{AB}(540,517,370,147$, and $152 \mathrm{bp})$ and $\mathrm{BB}(517,370,147$, and $152 \mathrm{bp})$.

Table 3. Allelic and genotypic frequencies for $\beta-L G, P R L$, and CSN3 genes in Awassi sheep.

\begin{tabular}{|c|c|c|c|c|c|c|c|}
\hline Gene $^{1}$ & Genotype & $\begin{array}{l}\text { Observed } \\
\text { Number }\end{array}$ & $\begin{array}{l}\text { Expected } \\
\text { Number }\end{array}$ & $\begin{array}{l}\text { Genotype } \\
\text { Frequency }\end{array}$ & Allele & $\begin{array}{c}\text { Allele } \\
\text { Frequency }\end{array}$ & $\begin{array}{c}\text { Value of } \\
x^{2} \text { Test }\end{array}$ \\
\hline \multirow{3}{*}{$\beta-L G(\mathrm{n}=159)$} & $\mathrm{AA}$ & 27 & 28.7 & 0.17 & A & 0.42 & $0.29^{\mathrm{ns}}$ \\
\hline & $\mathrm{AB}$ & 81 & 77.7 & 0.51 & B & 0.58 & \\
\hline & BB & 51 & 52.7 & 0.32 & & & \\
\hline \multirow{3}{*}{$P R L(\mathrm{n}=158)$} & $\mathrm{AA}$ & 115 & 107 & 0.73 & A & 0.82 & $19.2^{\mathrm{ns}}$ \\
\hline & $\mathrm{AB}$ & 30 & 46.1 & 0.19 & B & 0.18 & \\
\hline & $\mathrm{BB}$ & 13 & 5 & 0.08 & & & \\
\hline \multirow{2}{*}{ CSN3 $(\mathrm{n}=156)$} & $\mathrm{TT}$ & 132 & 132.9 & 0.85 & $\mathrm{~T}$ & 0.92 & $1.1^{\mathrm{ns}}$ \\
\hline & $\mathrm{TC}$ & 24 & 22.1 & 0.15 & $\mathrm{C}$ & 0.08 & \\
\hline
\end{tabular}

${ }^{1} \beta$-LG = $\beta$-lactoglobulin; $P R L=$ prolactin; CSN3 = $\mathrm{k}$-casein; n: number of animals; ns: Non-significant $(p>0.05)$, $\mathrm{n}=$ number of genotyped individuals 

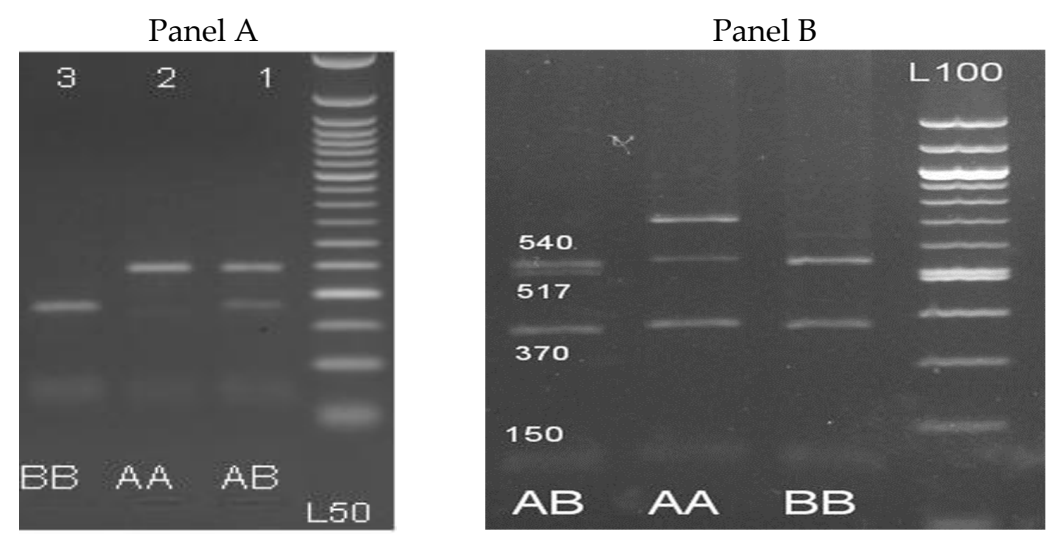

Figure 1. PCR-RFLP results for $\beta-L G$ (A) and prolactin (B) genes using RsaI and HaeIII restriction enzyme respectively on 3\% agarose gel. Panel A: Lanes 1, 2 and 3 are: AB (241, 175, 66 and 60 bp), AA (241 and $60 \mathrm{bp})$, and BB (175, 66 and $60 \mathrm{bp})$ genotypes, and L50: Ladder 50bp. Panel B: Lanes 1, 2 and 3 are: $\mathrm{BB}(517,370,147$, and $151 \mathrm{bp})$, AA (540, 370, 147, and $151 \mathrm{bp})$, and $\mathrm{AB}$ (540, 517, 370, 147, and 151 bp) genotypes, and L100: Ladder $100 \mathrm{bp}$.

\subsection{Nucleotide Sequence Analysis of the $\beta-L G$ and CSN3 Gene}

A successfully amplified 680 bp specific fragment of CSN3 gene was achieved (Supplementary, Figure S1). The sequencing of the PCR products with specific primers was performed, and the alignment and the analysis of the sequences were conducted by Bio Edit software program (Supplementary, Figure S2). In addition, showed the mutation a Kappa casein SNP rs407795524 mutation located at Chr. No: 6:85316423bp and a $\beta$-Lactoglobulin Rs430610497mutation located at 1373 bp in Awassi sheep exon 2.

\subsection{Genotypic and Allelic Frequencies for $\beta-L G, P R L$, and CSN3 Genes}

The genotypic and allelic frequencies of the $\beta-L G, P R L$, and CSN3 genes are summarized in Table 3 . The $\beta-L G$ gene frequency had a greater prevalence of the $\mathrm{B}$ allele (0.58). $\mathrm{BB}$ and $\mathrm{AB}$ genotypes were predominant in the population, with frequencies of 0.32 and 0.51 , respectively. The frequencies of alleles $\mathrm{A}$ and $\mathrm{B}$ at $P R L$ locus were 0.82 and 0.18 , respectively resulting in AA genotype being the most frequent (0.73). However, the CSN3 gene polymorphism in this population was more restricted due to the higher frequency of the T allele (0.92), with very high frequencies for the TT (0.85) compared to TC (0.15) genotype. This result showed that $\mathrm{T}$ allele was of higher frequency than $\mathrm{C}$ allele, the assumed $\mathrm{CC}$ genotype of CSN3 gene was not found in the studied Awassi population. Furthermore, the probability of deviations from the Hardy-Weinberg equilibrium for the three genes were based on chi-square test $\left(x^{2}\right)$ and showed that all genotypic frequencies in the population were in Hardy-Weinberg equilibrium $(p<0.05)$ (Table 2).

\subsection{Statistical Analysis of the Effects of $\beta-L G, P R L$, and CSN3 Genotypes on Milk Production and Component Traits}

The fixed effects on milk production and some milk composition traits are presented in Table 4 and showed that sire, parity, and year-season of lambing had highly significant effects on milk production traits $(p<0.05)$. However, the $\beta-L G$ and CSN3 gene had no effect $(p>0.05)$ on milk production traits (TMY and TDM), in contrast to the $P R L$ gene $(p<0.05)$. Milk production traits were significantly affected by the interaction between $\beta-L G$ and PRL genes $(p<0.05)$, while milk production did not differ between the pairs of other combination genes genotypes interactions $(\beta-L G \times C S N 3$, and PRL $\times C S N 3$ genes) $(p>0.05)$.

Furthermore, the $\beta-L G$ gene had significant effects on all milk composition traits $(p<0.05)$. $P R L$ gene significantly $(p<0.05)$ affected all milk composition traits except fat $\%$. Out of all the studied composition traits, CSN3 gene had an effect only on SNF\% $(p<0.05)$ (Table 4). Also, sire had highly significant effects on all milk composition traits $(p<0.05)$, while the effect of parity was not significant $(p>0.05)$. Combined gene genotypes also showed significant $(p<0.05)$ interaction effects between 
$\beta-L G$ and PRL on all milk composition traits, while the interactions between $\beta-L G$ and CSN3 did not show significant effects $(p>0.05)$. This interaction can be clearly seen in Table 4 , where the interaction between PRL and CSN3 gene significantly altered $(p<0.05)$ only fat $\%$ and $S N F \%$.

Table 4. $p$-values for milk production and composition traits.

\begin{tabular}{|c|c|c|c|c|c|c|c|}
\hline \multirow[b]{2}{*}{ Factors } & \multicolumn{2}{|c|}{ Milk Production $^{1}$} & \multicolumn{5}{|c|}{ Milk Components ${ }^{2}$} \\
\hline & $\begin{array}{l}\text { TMY } \\
\text { (kg) }\end{array}$ & $\begin{array}{c}\text { TDM } \\
\text { (kg) }\end{array}$ & Fat $\%$ & SNF\% & Protein $\%$ & Lactose $\%$ & $\begin{array}{c}\text { Density, } \\
\mathrm{g} / \mathrm{cm}^{2}\end{array}$ \\
\hline$\beta-L G$ & 0.175 & 0.134 & 0.047 & $<0.0001$ & 0.046 & 0.03 & 0.002 \\
\hline$P R L$ & 0.034 & 0.011 & 0.761 & 0.001 & 0.035 & 0.05 & 0.005 \\
\hline CSN3 & 0.812 & 0.275 & 0.172 & 0.048 & 0.424 & 0.104 & 0.541 \\
\hline Sire & $<0.0001$ & $<0.0001$ & $<0.0001$ & $<0.0001$ & 0.019 & 0.035 & 0.0004 \\
\hline Parity & 0.004 & 0.005 & 0.056 & 0.412 & 0.389 & 0.266 & 0.665 \\
\hline Year & 0.003 & 0.002 & & & & & \\
\hline$\beta-L G \times P R L$ & 0.039 & 0.031 & 0.001 & $<0.0001$ & 0.008 & 0.035 & 0.05 \\
\hline$\beta-L G \times C S N 3$ & 0.874 & 0.221 & 0.417 & 0.899 & 0.784 & 0.949 & 0.496 \\
\hline$P R L \times C S N 3$ & 0.177 & 0.104 & 0.002 & 0.02 & 0.228 & 0.115 & 0.767 \\
\hline Dam weight at lambing & 0.299 & 0.009 & & & & & \\
\hline Test-day milk & & & 0.004 & 0.002 & 0.0004 & 0.481 & $<0.0001$ \\
\hline
\end{tabular}

${ }^{1}$ mixed-model analysis of fixed effects; ${ }^{2}$ analysis of some milk component factors. TMY: total milk yield; TDM: test-day milk; SNF: Solids-Non-Fat; $\beta-L G=\beta$-lactoglobulin; $P R L=$ prolactin; $C S N 3=\mathrm{K}$-casein

\subsection{Effects of $\beta-L G, P R L$, and CSN3 Genotypes on Milk Production Traits and Their Interactions}

The effect of $\beta-L G, P R L$, and CSN3 genotypes on milk production of Awassi sheep are shown in Table 5. Although the results indicated that the AA and BB genotypes produced the highest milk production (TMY and TDM) compared to the AB genotype, no significant differences $(p>0.05)$ were observed between the genotype groups of $\beta$-LG. For PRL gene, AA genotype was associated with the highest milk production compared to AB genotype, while no significant differences $(p>0.05)$ in milk production were observed between the AA and BB genotypes. The CSN3 gene showed no significant association with milk production traits (Table 5).

The least square means $( \pm \mathrm{SE})$ for the effect of interaction between $\beta$ - $L G \times P R L$ genotypes on milk production traits are shown in Table 5. The results for the $\beta-L G \times P R L$ indicated that $\mathrm{AA} \times \mathrm{BB}$ was significantly associated with maximum TMY and TDM compared to the other genotypes.

Table 5. Effect of Beta lactoglobuline ( $\beta-L G)$, Prlactin (PRL), and Kappa casein (CSN3) genotypes and significant interaction effects on milk production traits in Awassi sheep.

\begin{tabular}{|c|c|c|c|c|}
\hline \multirow{2}{*}{ Gene } & \multirow{2}{*}{ Genotype } & \multirow{2}{*}{$\mathbf{N}$} & \multicolumn{2}{|c|}{ Trait Least Square Means ( \pm SE) } \\
\hline & & & TMY (Kg) & TDM (Kg) \\
\hline \multirow{3}{*}{$\beta-L G$} & AA & 51 & $100.4 \pm 13.4$ & $0.718 \pm 0.10$ \\
\hline & $\mathrm{AB}$ & 145 & $72.2 \pm 15.7$ & $0.606 \pm 0.10$ \\
\hline & BB & 96 & $93.2 \pm 12.6$ & $0.801 \pm 0.10$ \\
\hline \multirow{3}{*}{$P R L$} & AA & 197 & $102.4 \pm 9.86^{\mathrm{a}}$ & $0.814 \pm 0.08^{a}$ \\
\hline & $\mathrm{AB}$ & 68 & $71.4 \pm 12.6^{b}$ & $0.540 \pm 0.10^{b}$ \\
\hline & BB & 27 & $92.0 \pm 14.7^{\mathrm{ab}}$ & $0.770 \pm 0.11^{\mathrm{a}}$ \\
\hline \multirow{2}{*}{ CSN3 } & TT & 240 & $90.1 \pm 11.8$ & $0.762 \pm 0.09$ \\
\hline & $\mathrm{TC}$ & 52 & $87.1 \pm 11.5$ & $0.654 \pm 0.09$ \\
\hline \multirow{9}{*}{$\begin{array}{l}\vec{a} \\
a \\
x \\
x \\
0 \\
-1 \\
d \\
d\end{array}$} & AAAA & 29 & $96.5 \pm 13.0^{b}$ & $0.780 \pm 0.10^{\mathrm{ab}}$ \\
\hline & AAAB & 12 & $65.0 \pm 23.0^{b c}$ & $0.359 \pm 0.17^{\mathrm{c}}$ \\
\hline & AABB & 10 & $139.7 \pm 25.2^{\mathrm{a}}$ & $1.02 \pm 0.19^{\mathrm{a}}$ \\
\hline & ABAA & 106 & $99.2 \pm 17.3^{\mathrm{ab}}$ & $0.834 \pm 0.13^{\mathrm{ab}}$ \\
\hline & $\mathrm{ABAB}$ & 31 & $72.6 \pm 19.3^{b c}$ & $0.578 \pm 0.15^{\mathrm{c}}$ \\
\hline & ABBB & 8 & $44.9 \pm 18.4^{\mathrm{c}}$ & $0.406 \pm 0.14^{c}$ \\
\hline & BBAA & 62 & $111.6 \pm 11.1^{\mathrm{ab}}$ & $0.829 \pm 0.08^{a b}$ \\
\hline & BBAB & 25 & $76.8 \pm 15.4^{b c}$ & $0.684 \pm 0.12^{b}$ \\
\hline & BBBB & 9 & $91.3 \pm 27.6^{a b}$ & $0.891 \pm 0.21 \mathrm{ab}$ \\
\hline
\end{tabular}

Within the same column different letters indicate significant differences $p<0.05$. 


\subsection{Effects of $\beta-L G, P R L$, and CSN3 Genotypes on Milk Composition Traits and Their Interactions}

Table 6 illustrates the results obtained for the effect of $\beta-L G, P R L$ and CSN3 genotypes on milk composition traits of Awassi sheep and the different interactions between the various genotypes. The $\mathrm{AA}$ and $\mathrm{BB}$ genotypes of $\beta-L G$ gene were associated with the highest fat levels (6.63 and 6.30, respectively), while $\mathrm{AB}$ genotype with the lowest (5.31) $(p<0.05)$. The $\mathrm{BB}$ genotype of $\beta$ - $L G$ gene also showed significant $(p<0.05)$ association with the highest $\mathrm{SNF} \%$, protein $\%$ and lactose $\%$ compared to the $\mathrm{AA}$ and $\mathrm{AB}$ genotypes.

Table 6. Effect of $\beta-L G, P R L$, and CSN3 genotypes and their interacting effects on milk composition traits in Awassi sheep.

\begin{tabular}{|c|c|c|c|c|c|c|c|}
\hline \multirow{2}{*}{ Gene } & \multirow{2}{*}{ Genotype } & \multirow{2}{*}{$\mathbf{N}$} & \multicolumn{5}{|c|}{ Traits Least Square Means ( \pm SE) } \\
\hline & & & Fat $\%$ & SNF $\%$ & Protein $\%$ & Lactose $\%$ & Density, $\mathrm{g} / \mathrm{cm}^{2}$ \\
\hline \multirow{3}{*}{$\underset{c}{0}$} & AA & 112 & $6.63 \pm 0.29^{a}$ & $9.50 \pm 0.15^{b}$ & $3.90 \pm 0.10^{b}$ & $4.99 \pm 0.14^{b}$ & $33.0 \pm 0.61^{b}$ \\
\hline & $\mathrm{AB}$ & 376 & $5.31 \pm 0.43^{b}$ & $9.39 \pm 0.22^{b}$ & $3.66 \pm 0.14^{b}$ & $4.88 \pm 0.20^{b}$ & $34.1 \pm 0.87^{a b}$ \\
\hline & $\mathrm{BB}$ & 277 & $6.30 \pm 0.35^{\mathrm{a}}$ & $10.4 \pm 0.18^{\mathrm{a}}$ & $4.13 \pm 0.12^{\mathrm{a}}$ & $5.39 \pm 0.16^{\mathrm{a}}$ & $35.4 \pm 0.71^{\mathrm{a}}$ \\
\hline \multirow{3}{*}{$\vec{d}$} & AA & 554 & $6.13 \pm 0.17$ & $9.86 \pm 0.08^{a}$ & $4.00 \pm 0.06^{\mathrm{a}}$ & $5.02 \pm 0.08^{b}$ & $34.2 \pm 0.34^{\mathrm{a}}$ \\
\hline & $\mathrm{AB}$ & 159 & $5.96 \pm 0.19$ & $9.44 \pm 0.10^{b}$ & $3.79 \pm 0.06^{b}$ & $4.90 \pm 0.09^{b}$ & $32.9 \pm 0.40^{b}$ \\
\hline & $\mathrm{BB}$ & 52 & $6.15 \pm 0.38$ & $9.96 \pm 0.19^{a}$ & $3.91 \pm 0.13^{a b}$ & $5.35 \pm 0.18^{a}$ & $35.3 \pm 0.77^{a}$ \\
\hline \multirow{2}{*}{ 己̌ } & TT & 624 & $6.49 \pm 1.45$ & $10.1 \pm 0.19^{\mathrm{a}}$ & $3.98 \pm 0.12$ & $5.32 \pm 0.17$ & $34.5 \pm 0.75$ \\
\hline & $\mathrm{TC}$ & 141 & $5.67 \pm 1.05$ & $9.45 \pm 0.15^{b}$ & $3.82 \pm 0.10$ & $4.86 \pm 0.14$ & $33.7 \pm 0.62$ \\
\hline \multirow{9}{*}{ 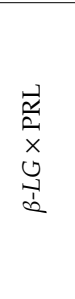 } & AAAA & 56 & $6.38 \pm 0.34^{b c}$ & $9.77 \pm 0.17^{b}$ & $4.05 \pm 0.11^{b}$ & $4.87 \pm 0.16^{c}$ & $33.6 \pm 0.70^{b}$ \\
\hline & AAAB & 29 & $5.56 \pm 0.45^{c}$ & $8.63 \pm 0.21^{c}$ & $3.47 \pm 0.14^{c}$ & $4.46 \pm 0.19^{d}$ & $30.2 \pm 0.84^{c}$ \\
\hline & AABB & 27 & $7.95 \pm 0.82^{\mathrm{a}}$ & $10.1 \pm 0.42^{b}$ & $4.18 \pm 0.28^{a b}$ & $5.66 \pm 0.39^{a b}$ & $35.2 \pm 1.71^{a b}$ \\
\hline & ABAA & 284 & $5.97 \pm 0.24^{c}$ & $9.87 \pm 0.11^{b}$ & $3.99 \pm 0.08^{b}$ & $5.06 \pm 0.10^{b c}$ & $34.6 \pm 0.46^{b}$ \\
\hline & $\mathrm{ABAB}$ & 78 & $6.67 \pm 0.30^{b}$ & $9.97 \pm 0.15^{b}$ & $3.97 \pm 0.10^{b}$ & $5.24 \pm 0.14^{b}$ & $34.5 \pm 0.61^{b}$ \\
\hline & $\mathrm{ABBB}$ & 14 & $3.28 \pm 1.11^{\mathrm{d}}$ & $8.33 \pm 0.57^{c}$ & $3.02 \pm 0.38^{c}$ & $4.35 \pm 0.50^{\mathrm{cd}}$ & $33.3 \pm 2.30^{b c}$ \\
\hline & BBAA & 214 & $6.03 \pm 0.18^{c}$ & $9.92 \pm 0.09^{b}$ & $3.96 \pm 0.06^{b}$ & $5.12 \pm 0.08 \mathrm{bc}$ & $34.6 \pm 0.36^{b}$ \\
\hline & BBAB & 52 & $5.63 \pm 0.38^{c}$ & $9.72 \pm 0.15^{b}$ & $3.91 \pm 0.10^{b}$ & $4.99 \pm 0.14 \mathrm{bc}$ & $34.1 \pm 0.59^{b}$ \\
\hline & BBBB & 11 & $7.23 \pm 1.03^{\mathrm{ab}}$ & $11.5 \pm 0.52^{\mathrm{a}}$ & $4.53 \pm 0.35^{\mathrm{a}}$ & $6.05 \pm 0.48^{a}$ & $37.4 \pm 2.10^{a}$ \\
\hline \multirow{6}{*}{$\begin{array}{l}\sum_{\mathcal{W}}^{\infty} \\
\times \\
\frac{a}{a}\end{array}$} & AATT & 478 & $6.13 \pm 0.18^{b}$ & $9.89 \pm 0.08^{b}$ & $3.95 \pm 0.05$ & $5.11 \pm 0.07$ & $34.5 \pm 0.32$ \\
\hline & AATC & 75 & $6.12 \pm 0.27^{b}$ & $9.82 \pm 0.13^{b c}$ & $4.05 \pm 0.09$ & $4.93 \pm 0.12$ & $33.9 \pm 0.54$ \\
\hline & ABTT & 122 & $5.32 \pm 0.22^{c}$ & $9.29 \pm 0.11^{d}$ & $3.68 \pm 0.46$ & $4.83 \pm 0.17$ & $32.9 \pm 1.02$ \\
\hline & ABTC & 37 & $6.59 \pm 0.32^{b}$ & $9.59 \pm 0.16^{c}$ & $3.89 \pm 0.11$ & $4.68 \pm 0.15$ & $32.9 \pm 1.45$ \\
\hline & BBTT & 23 & $8.02 \pm 1.11^{a}$ & $11.0 \pm 0.57^{\mathrm{a}}$ & $4.31 \pm 0.38$ & $6.03 \pm 1.12$ & $36.2 \pm 2.30$ \\
\hline & BBTC & 29 & $4.29 \pm 0.75^{\mathrm{d}}$ & $8.93 \pm 0.38^{d}$ & $3.51 \pm 0.62$ & $4.68 \pm 0.35$ & $34.5 \pm 1.55$ \\
\hline
\end{tabular}

Within the same column different letters indicate significant differences $p<0.05$.

Specifically, the $\beta-L G$ BB genotype was associated with the highest milk density compared to AA genotype $\left(35.4 \pm 0.71,33.0 \pm 0.61 \mathrm{~g} / \mathrm{cm}^{2}, p<0.05\right.$, respectively), but not to genotype $\mathrm{AB}\left(34.1 \pm 0.87 \mathrm{~g} / \mathrm{cm}^{2}\right.$, $p>0.05)$. In relation to the $P R L$ gene, no significant differences among $P R L$ genotypes were found in fat $\%$, while the AA and BB genotype were associated with the high SNF\% compared with $A B$ genotype. Greater protein percentages were recorded for AA compared to AB genotypes, but not BB. The highest lactose percentage was found in the BB genotype of $P R L$ gene $(5.35 \pm 0.18 \%)$ compared to the AA and AB genotypes (5.02 $\pm 0.08 \%, 4.90 \pm 0.09 \%$, respectively). Moreover, AA and BB genotypes produced the highest milk density compared to AB genotype. For the CSN3 gene, TT genotype was associated with the highest levels of SNF\% $(10.1 \pm 0.19 \%)$, while the TC was associated with the lowest $(9.45 \pm 0.15 \%)$. Nonetheless, no significant differences were found among CSN3 genotypes in milk components including fat $\%$, protein $\%$, lactose $\%$, and milk density $(p>0.05)$.

Compared to their other respective genotypes; $\mathrm{AA} \times \mathrm{BB}$ genotype $(\beta-L G \times P R L)$ showed the highest fat $\%, \mathrm{BB} \times \mathrm{BB}$ genotype $(\beta-L G \times P R L)$ recorded the highest $\mathrm{SNF} \%$, protein $\%$, lactose $\%$ and milk density, and BBxTT genotype (PRL $\times$ CSN3) scored the highest fat $\%$ and $\mathrm{SNF} \%$. Interaction differences among $P R L \times C S N 3$ genotypes in protein $\%$ and lactose $\%$ and milk density $(p>0.05)$ were not significant. 


\section{Discussion}

This study reports the association between $\beta-L G, P R L$, and CSN3 genes and milk production and composition of Awassi sheep. These genes were chosen because of their direct involvement in the growth and development of the mammary gland, maintenance of milk secretion, and synthesis of milk $[2,12,14,15,22,31]$. The genes are also located in the region of QTL influencing milk quantity and quality $[12,14,15,22,23]$. This study revealed that in Awassi sheep, these genes present different allelic frequencies and genotypes (Table 2).

$\beta$-LG locus showed a higher frequency of allele B (0.58) than allele A (0.42) in Awassi sheep. Similar results were found in Chios sheep breed [19], Racka Sheep [32], Rusty Tsigai breed [33], Zel breed [20], Polish Merino breed [34], and Awassi breed [3,35]. No evidence was found for C allele in our study, which is considered a rare variant detected only in a few breeds such as Turcana, Racka, Tsigai, Karakul of Botosani, Transylvanian Merino, Merinoland, and Hungarian Merino [15,36].

In agreement with other studies, the frequency of PRL A allele (0.82) was more than B allele (0.18); Allele frequency was found at 0.64 in Spanish Merino sheep [14], 0.53 in Black Head sheep breed [12], 0.75 in Awassi sheep [37], 0.64 in Serra da Estrela, 0.57 in White Merino, and 0.72 in Black Merino [38].

However, the gene frequency for the CSN3 locus in Awassi sheep reported in this study differed from East Friesian sheep [16] and Black Head sheep [12] where the T and C alleles were of equal frequencies.

The findings presented in this paper indicated that $\beta-L G$ gene polymorphisms are not associated with milk production traits in Awassi sheep (Table 4). These results are in agreement with previous studies reported by Padilla et al. [14] in Spanish Merino sheep, Triantaphyllopoulos et al. [19] in Karagouniko and Chios sheep breeds, Giambra et al. [39] in East Friesian Dairy and Lacaune sheep, Kaweka and Radko [34] in Polish Mountain, Polish Merino, East Friesian and Bergschaf, and Staiger et al. [16] in East Friesian sheep where the effect of $\beta-L G$ variants on milk yield was not indicated. Although $\beta$-LG gene did not show any associations with high milk yield, inverse response over milk composition must be considered in marker assisted selection (MAS) strategy. We found that the AA and $\mathrm{BB}$ genotypes of $\beta$-LG gene were associated with the highest fat percentage compared to AB genotype. Some previous studies reported significant effects of $\beta-L G$ on fat content in milk of different sheep breeds. Positive effects on milk fat content varied depending on sheep breed and $\beta$ - $L G$ genotype; $\beta$ - $L G$ BB genotype had a significant effect on milk fat percentage in Awassi sheep [40], AA and AB genotypes in Italian Altamurana and Leccese sheep [41], AA genotype in Merino sheep [42] and East Friesian Dairy sheep [39], AB genotype in Zel breed [20]. A recent study conducted by Padilla et al. [14] on the Spanish Merino sheep showed that $\beta-L G$ A allele had positive significant effects on fat percentage.

We also found that the BB variant of the $\beta-L G$ gene had a very large positive effect on protein $\%$, $\mathrm{SNF} \%$, lactose $\%$, and milk density compared to AB and AA genotypes (Table 4). These results were consistent with many previous studies where a strong association of the BB variant with protein percentage $[43,44]$ and lactose content $[19,20,45]$, but inconsistent in regard to SNF\% $[34,41,44,46]$ and milk density [20].

When analyzing the PRL genotypes effects on milk production traits, the AA genotype was associated with the highest milk production (Table 5). This result is consistent with some published results $[12,13,16]$ who reported a significant difference confirming the superiority of the PRL AA genotype in milk yield. However, fat percentage was not significantly affected by the $P R L$ genotype (Table 6) consistent with some published reports [14,38]. Moreover, contrary to available findings of BB genotype's superiority for protein percentage [12,14,38], our study found a stronger correlation with the AA genotype of the PRL gene compared to the AB and BB genotypes in Awassi ewes. Another study using Sakiz ewes, Ozmen and Kul [13] found that heterozygous AB ewes produced the highest milk protein percentage when compared to homozygous AA and BB genotypes animals, while there were no significant differences in protein percentage according to different genotypes in Akkaraman and Awassi ewes. PRL AA and BB genoty [13] pe also showed positive effects on SNF\% and milk density (Table 6); however, according to the literature, no other studies examined this association. 
This study also showed that the BB genotype of the PRL gene particularly was associated with higher production of lactose in milk compared with the $\mathrm{AA}$ and $\mathrm{AB}$ genotypes. In contrast to these results, Ozmen and Kul [13] reported lack of association between lactose content and PRL genotypes in Sakiz, Akkaraman, and Awassi ewes.

Our results did not show any significant effect of the CSN3 variants on milk production traits as seen in the milk yield of Black Head sheep [12] and East Friesian sheep [16]. We found no significant effect of CSN3 variants on fat, protein, lactose content, and milk density, whereas SNF content was positively affected by only the TT genotype (Table 6). Gras et al. [12] also reported no associations when his team examined the influence of CSN3 polymorphism on fat and protein content in Black Head sheep. On the other hand, Yousefi et al. [20] reported that the k1 pattern of the CSN3 locus affected only lactose percentage in milk and milk density in Zel sheep.

The interesting portion of this project was the combined genotype effect on milk production and composition; genotype combination reflects the interactions of multiple genes effects in a certain quantitative trait [47]. Our study only found a significant impact of the interaction of $\beta-L G^{*} P R L$ genotypes on milk production (Table 6), while PRL $\times$ CSN3 and $\beta-L G \times C S N 3$ genotypes showed minimal combined effects. $(p<0.05)$. Mile production was highest in Awassi ewes of AA $\times$ BB $(\beta-L G \times$ PRL) combined genotypes compared to the ABxBB genotype. While milk composition only improved in the $\beta-L G \times$ PRL and PRL $\times$ CSN3 genotypes compared to $\beta-L G \times C S N 3(p<0.05)$. The statistical results show that ewes of $\mathrm{AA} \times \mathrm{BB}$ genotype combination had the highest fat $\%$, and $\mathrm{BB} \times \mathrm{BB}$ genotype combination had the highest $\mathrm{SNF} \%$, protein $\%$, lactose $\%$ and milk density compared to other genotypes (Table 6). The highest fat $\%$ and $\mathrm{SNF} \%$ were recorded for the $\mathrm{BB} \times \mathrm{TT}$ genotype $(\mathrm{PRL} \times \mathrm{CSN} 3)$ compared to the other genotypes.

\section{Conclusions}

The findings presented in this paper indicated that $\beta-L G$ gene polymorphisms are not associated with milk production traits, but rather with varying fat $\%$, protein $\%$, SNF $\%$, lactose $\%$, and even density. PRL gene polymorphism was associated with positively with $\mathrm{SNF} \%$, lactose $\%$ and milk density but not fat $\%$ or protein $\%$. Furthermore, there was no CSN3 variants effects on milk production or composition traits in Awassi ewes.

The interesting portion of this project was the combined genotype effect on milk production and composition where we showed a significant impact of the interaction of $\beta-L G \times P R L$ genotypes on milk production and of PRL $\times$ CSN3 on fat $\%$ and SNF\%, while minimal combined effects for PRL $\times$ CSN3 and $\beta-L G \times C S N 3$ genotypes were detected.

Although our study showed the great potential of these three genes and their variants on improving milk yield and composition traits, the interaction and combined effects of these genes should be studied further in order to incorporate them in breeding strategies to improve milk production and composition of Awassi sheep.

Supplementary Materials: The following are available online at http://www.mdpi.com/2076-2615/9/6/382/s1, Figure S1: $\mathrm{k}$-casein (CSN3) gene PCR product, lanes 1 and 2 is the 680bp PCR product and L50: Ladder 50bp, Figure S2: Sequencing of Kappa Casein and $\beta$-Lactoglobulin in Awassi sheep. Panel I. Kappa casein SNP rs407795524 mutation detected by sequencing in Awassi sheep A: TC, B: TT and C: CC located at Chr. No: 6:85316423bp; Panel II: Rs430610497 mutation that located at 1373bp in Awassi sheep exon 2 of $\beta$-Lactoglobulin gene A: Heterozygous TC, B: CC and C: TT genotype.

Author Contributions: Conceptualization and methodology, validation, formal analysis, investigation, resources, data collection, sequence analysis writing —original draft preparation; writing — review and editing: K.I.J., A.H.A. and P.Y.A.; DNA extraction, Genotyping, and data analysis: K.I.J and A.H.A. All authors read and approved the final manuscript.

Funding: This project was funded by the Deanship of Research of Jordan University of Science and Technology (JUST), grant \# 0301/2017.

Acknowledgments: Livestock and Range land research directorate of the NCARE (recently renamed to NARC) staff.

Conflicts of Interest: The authors declare that they have no conflicts of interest. 


\section{References}

1. Carta, A.; Casu, S.; Salaris, S. Invited review: Current state of genetic improvement in dairy sheep. J. Dairy Sci. 2009, 92, 5814-5833. [CrossRef] [PubMed]

2. Selvaggi, M.; Laudadio, V.; Dario, C.; Tufarelli, V. Investigating the genetic polymorphism of sheep milk proteins: A useful tool for dairy production. J. Sci. Food Agric. 2014, 94, 3090-3099. [CrossRef] [PubMed]

3. Jawasreh, K.I. Quantitative and molecular genetic analysis for some traits in highly selected jordanian awassi sheep for milk production. In Proceedings of the World Congress on Genetics Applied to Livestock Production, Volume Species Breeding: Sheep and Goat Breeding for Milk, Meat and Fibre-Lecture Sessions, Leipzig, Germany, 1-6 August 2010; p. 93.

4. Ahmed, M.; Abdallah, J. Comparison of milk yield and reproductive performance of sheep breeds in the West Bank, Palestine. An Najah Univ. J. Res. 2013, 27, 11-128.

5. Al-Samarai, F.R.; Al-Anbari, N.N. Genetic evaluation of rams for total milk yield in Iraqi Awassi sheep. ARPN J. Agri. Biol. Sci. 2009, 4, 54-57.

6. Dag, B.; Keski, I.; Mikailsoy, F. Application of different models to the lactation curves of unimproved Awassi ewes in Turkey. S. Afr. J. Anim. Sci. 2005, 35, 238-243. [CrossRef]

7. Epstein, H.E. The Awassi sheep with special reference to the improved dairy type. In FAO Animal Production, Health Paper 57; FAO: Rome, Italy, 1985.

8. Gootwine, E. Mini review: Breeding Awassi and Assaf sheep for diverse management conditions. Trop. Anim. Health Prod. 2011, 43, 1289-1296. [CrossRef] [PubMed]

9. Iniguez, L.; Hilali, M.E.D. Evaluation of Awassi genotypes for improved milk production in Syria. Livest. Sci. 2009, 120, 232-239. [CrossRef]

10. Eggen, A. The development and application of genomic selection as a new breeding paradigm. Anim. Front. 2012, 2, 10-15. [CrossRef]

11. Barillet, F.; Arranz, J.J.; Carta, A. Mapping quantitative trait loci for milk production and genetic polymorphisms of milk proteins in dairy sheep. Genet. Sel. Evol. 2005, 37, 109-123. [CrossRef]

12. Gras, M.; Pistol, G.; Pelmus, R.; Lazar, C.; Grosu, H.; Ghita, E. Relationship between gene polymorphism and milk production traits in Teleorman Black Head sheep breed. Rev. MVZ Córdoba 2016, 21, 5124-5136. [CrossRef]

13. Ozmen, O.; Kul, S. Identification of novel SNPs of ovine PRL gene and their association with milk production traits. Russian J. Genet. 2016, 52, 977-984. [CrossRef]

14. Padilla, P.; Izquierdo, M.; Martínez-Trancón, M.; Parejo, J.C.; Rabasco, A.; Salazar, J.; Padilla, J.Á. Polymorphisms of $\alpha$-lactoalbumin, $\beta$-lactoglobulin and prolactin genes are highly associated with milk composition traits in Spanish Merino sheep. Livest. Sci. 2018, 217, 26-29. [CrossRef]

15. Selvaggi, M.; Laudadio, V.; Dario, C.; Tufarelli, V. $\beta$-Lactoglobulin gene polymorphisms in sheep and effects on milk production traits: A review. Adv. Anim. Vet. Sci. 2015, 3, 478-484. [CrossRef]

16. Staiger, E.A.; Thonney, M.L.; Buchanan, J.W.; Rogers, E.R.; Oltenacu, P.A.; Mateescu, R.G. Effect of prolactin, beta-lactoglobulin, and kappa-casein genotype on milk yield in East Friesian sheep. J. Dairy Sci. 2010, 93, 1736-1742. [CrossRef]

17. Erhardt, G. Evidence for a third allele at the $\beta$-lactoglobulin $(\beta$-Lg) locus of sheep milk and its occurrence in different breeds. Anim. Genet. 1989, 20, 197-204. [CrossRef] [PubMed]

18. Moioli, B.; D'Andrea, M.; Pilla, F. Candidate genes affecting sheep and goat milk quality. Small Rumin. Res. 2007, 68, 179-192. [CrossRef]

19. Triantaphyllopoulos, K.; Koutsouli, P.; Kandris, A.; Papachristou, D.; Markopoulou, K.; Mataragka, A.; Massouras, T.; Bizelis, I. Effect of $\beta$-lactoglobulin gene polymorphism, lactation stage and breed on milk traits in Chios and Karagouniko sheep breed. Ann. Anim. Sci. 2017, 17, 371-384. [CrossRef]

20. Yousefi, S.; Azari, M.A.; Zerehdaran, S.; Samiee, R.; Khataminejhad, R. Effect of $\beta$-lactoglobulin and k-casein genes polymorphism on milk composition in indigenous Zel sheep. Arch. Anim. Breed. 2013, 56, $216-224$. [CrossRef]

21. Orford, M.; Tzamaloukas, O.; Papachristoforou, C.; Miltiadou, D. Technical note: A simplified PCR-based assay for the characterization of two prolactin variants that affect milk traits in sheep breeds. J. Dairy Sci. 2010, 93, 5996-5999. [CrossRef] 
22. Gras, M.A.; Rotar, C.M.; Pelmus, R.S.; Lazar, C.; Ghita, E.; Grosu, H. Prolactin polymorphism effect over production traits types at Transylvanian Merino sheep. Sci. Papers Anim. Sci. Biotechnol. Lucrari Stiintifice Zootehnie si Biotehnologii 2017, 50, 56-60.

23. Suarez-Vega, A.; Gutierrez-Gil, B.; Klopp, C.; Tosser-Klopp, G.; Arranz, J.J. Variant discovery in the sheep milk transcriptome using RNA sequencing. BMC Genom. 2017, 18, 170. [CrossRef] [PubMed]

24. Park, Y.W.; Juárez, M.; Ramos, M.; Haenlein, G.F.W. Physico-chemical characteristics of goat and sheep milk. Small Rumin. Res. 2007, 68, 88-113. [CrossRef]

25. Feligini, M.; Vlaco, S.; Curik, V.C.; Parma, P.; Greppi, G.; Enne, G. A single nucleotide polymorphism in the sheep kappa-casein coding region. J. Dairy Res. 2005, 72, 317-321. [CrossRef] [PubMed]

26. Othman, O.; El-Fiky, S.A.; Hassan, N.; Mahfouz, E.; Balabel, E. Genetic variations of $\beta$ - and K-casein genes in Egyptian sheep breeds. J. Appl. Biosci 2013, 64, 4858-4866. [CrossRef]

27. Nassiri, M.; Heravi-Moussavi, A.; Raoof Alashawkany, A.; Ghovati, S. Leptin gene polymorphism in Iranian native Golpayegani and Taleshi cows. Pakistan J. Biol. Sci. 2007, 10, 3738-3741. [CrossRef]

28. Vincent, A.L.; Wang, L.; Tuggle, C.K.; Robic, A.; Rothschild, M.F. Prolactin receptor maps to pig chromosome 16. Mamm. Genome 1997, 8, 793-794. [CrossRef] [PubMed]

29. Hall, T.A. BioEdit: A User-Friendly Biological Sequence Alignment Editor and Analysis Program for Windows 95/98/NT. Nucleic Acids Symposium Series 1999, 41, 95-98.

30. Yeh, F.C.; Yang, R.C.; Boyle, T. POPGENE Version 1.32: Microsoft Window-Based Freeware for Population Genetics Analysis; University of Alberta: Edmonton, AB, Canada, 1999. [CrossRef]

31. Knight, C. Overview of prolactin's role in farm animal lactation. Livest. Prod. Sci. 2001, 70, 87-93. [CrossRef]

32. Georgescu, S.E.; Ene, A.; Dudu, A.; Ghita, E.; Costache, M. Genetic polymorphisms of $\beta$-lactoglobulin and $\alpha$-s1-casein genes in Romanian Racka sheep. Sci. Pap. Anim. Sci. Biotechnol. 2016, 49, 50-53.

33. Kusza, S.; Sziszkosz, N.; Nagy, K.; Masala, A.; Kukovics, S.; Andras, J. Preliminary result of a genetic polymorphism of beta-lactoglobulin gene and the phylogenetic study of ten balkan and central european indigenous sheep breeds. Acta Biochim. Polon. 2015, 62, 109-112. [CrossRef]

34. Kawecka, A.; Radko, A. Genetic polymorphism of $\beta$-lactoglobulin in sheep raised for milk production. J. Appl. Anim. Res. 2011, 39, 68-71. [CrossRef]

35. Baranyi, M.; Kerekes, A.; Hiripi, L.; Bősze, Z. Preliminary data on beta-lactoglobulin genetic polymorphisms in Hungarian Awassi and Racka sheep. Anim. Sci. Biotechnol. 2010, 43, 1-4.

36. Kusza, S.; Ilie, D.; Sauer, M.; Nagy, K.; Atanasiu, T.S.; Dinu, G. Study of LGB gene polymorphisms of small ruminants reared in Eastern Europe. Czech. J. Anim. Sci. 2018, 63, 152-159. [CrossRef]

37. Jawasreh, K.; Al-Qaisi, A.T.; Awawdeh, F. Association between GDF9, FecB and Prolactin gene polymorphisms and prolificacy of Awassi sheep. In Proceedings of the 10th World Congress of Genetics Applied to Livestock Production, Vancouver, BC, Canada, 18-22 August 2014.

38. Ramos, A.M.; Matos, C.A.P.; Russo Almeida, P.A.; Bettencourt, C.M.V.; Matos, J.; Martins, Â.; Pinheiro, C.M.S.; Rangel-Figueiredo, T. Candidate genes for milk production traits in Portuguese dairy sheep. Small Rumin. Res. 2009, 82, 117-121. [CrossRef]

39. Giambra, I.J.; Brandt, H.; Erhardt, G. Milk protein variants are highly associated with milk performance traits in East Friesian Dairy and Lacaune sheep. Small Rumin. Res. 2014, 121, 382-394. [CrossRef]

40. Çelik, S.; Özdemir, S. $\beta$-Lactoglobulin variants in awassi and morkaraman sheep and their association with the composition and rennet clotting time of the milk. Turk. J. Vet. Anim. Sci. 2006, 30, 539-544. [CrossRef]

41. Dario, C.; Carnicella, D.; Dario, M.; Bufano, G. Genetic polymorphism of B-lactoglobulin gene and effect on milk composition in Leccese sheep. Small Rumin. Res. 2008, 74, 270-273. [CrossRef]

42. Corral, J.M. Associations between milk protein genetic polymorphisms and milk production traits in Merino sheep breed. Livest. Sci. 2010, 129, 73-79. [CrossRef]

43. Giaccone, P.; Di Stasio, L.; Macciotta, N.; Portolano, B.; Todaro, M.; Cappio-Borlino, A. Effect of $\beta$-lactoglobulin polymorphism on milk-related traits of dairy ewes analysed by a repeated measures design. J. Dairy Res. 2000, 67, 443-448. [CrossRef]

44. Mroczkowski, S.; Korman, K.; Erhardt, G.; Piwczyński, D.; Borys, B. Sheep milk protein polymorphism and its effect on milk performance of Polish Merino. Archiv. Fur Tierzu 2004, 47, 114-121.

45. Rozbicka-Wieczorek, A.; Radzik-Rant, A.; Rant, W.; Puppel, K. The effect of breed, $\beta$ lactoglobulin variants and somatic cell count on yield, chemical components and whey protein composition in milk of non-dairy sheep. J. Anim. Plant Sci. 2015, 25, 633-639. 
46. El-Shazly, S.A.; Mahfouz, M.E.; Al-Otaibi, S.A.; Ahmed, M.M. Genetic polymorphism in $\beta$-lactoglobulin gene of some sheep breeds in the Kingdom of Saudi Arabia (KSA) and its influence on milk composition. Afr. J. Biotechnol. 2012, 11, 4330-4337. [CrossRef]

47. Zheng, X.; Ju, Z.; Wang, J.; Li, Q.; Huang, J.; Zhang, A.; Zhong, J.; Wang, C. Single nucleotide polymorphisms, haplotypes and combined genotypes of LAP3 gene in bovine and their association with milk production traits. Mol. Biol. Rep. 2011, 38, 4053-4061. [CrossRef] [PubMed]

(c)

(C) 2019 by the authors. Licensee MDPI, Basel, Switzerland. This article is an open access article distributed under the terms and conditions of the Creative Commons Attribution (CC BY) license (http://creativecommons.org/licenses/by/4.0/). 